\title{
Masa hidup imago, progeni, dan kemampuan parasitisasi Anagyrus lopezi (De Santis) (Hymenoptera: Encyrtidae), parasitoid kutu putih singkong
}

\author{
Adult longevity, progenies, and parasitization capacity of \\ Anagyrus lopezi (De Santis) (Hymenoptera: Encyrtidae), \\ parasitoid of cassava mealybug \\ Juwita Suri Maharani ${ }^{*}$, Aunu Rauf ${ }^{2}$, Nina Maryana ${ }^{2}$ \\ ${ }^{1}$ Program Studi Entomologi, Departemen Proteksi Tanaman, Fakultas Pertanian, Institut \\ Pertanian Bogor, Jalan Kamper, Kampus IPB Dramaga, Bogor 16680 \\ ${ }^{2}$ Departemen Proteksi Tanaman, Fakultas Pertanian, Institut Pertanian Bogor \\ Jalan Kamper, Kampus IPB Dramaga, Bogor 16680
}

(diterima Januari 2018, disetujui Juni 2019)

\begin{abstract}
ABSTRAK
Parasitoid Anagyrus lopezi (De Santis) (Hymenoptera: Encyrtidae) diintroduksikan dari Thailand ke Indonesia pada tahun 2014 untuk mengendalikan hama asing invasif, kutu putih singkong Phenacoccus manihoti Matile-Ferrero (Hemiptera: Pseudococcidae). Penelitian dilakukan di laboratorium dengan tujuan untuk mengetahui potensi reproduksi, pengaruh pemberian larutan madu terhadap masa hidup imago, memelajari keperidian, progeni, dan respons $A$. lopezi terhadap peningkatan kerapatan inang. Penelitian dilaksanakan dengan memajankan nimfa instar-3 kutu putih pada parasitoid. Pengaruh perlakuan pakan madu terhadap masa hidup imago parasitoid dilakukan pada kondisi tanpa inang. Keperidian diukur berdasarkan banyaknya mumi yang terbentuk. Hasil penelitian menunjukkan betina hidup selama 3,7 hari dan jantan 3,2 hari bila hanya tersedia air. Masa hidup imago parasitoid berlangsung lebih lama bila tersedia madu. Parasitoid yang diberi larutan madu 50\% mampu hidup 6-9 kali lipat lebih lama dibandingkan dengan yang hanya diberi air. Selama hidupnya imago betina $A$. lopezi memarasit 96-287 kutu putih, dengan rataan 203,7 atau tingkat parasitisasi $34,6 \%$, serta $24,86 \%$ mengalami kematian karena kegiatan pengisapan inang. Masa perkembangan pradewasa dari telur hingga imago muncul berlangsung 17,97 dan 17,67 hari, berturut-turut untuk jantan dan betina. Rataan progeni per induk adalah 88,8 individu, dengan 56,9\% berjenis kelamin betina. Pada kerapatan inang 2-100 individu, parasitoid A. lopezi memperlihatkan tanggap fungsional tipe III.
\end{abstract}

Kata kunci: Anagyrus lopezi, kutu putih singkong, parasitoid, Phenacoccus manihoti

\begin{abstract}
Parasitoid Anagyrus lopezi (De Santis) (Hymenoptera: Encyrtidae) was introduced from Thailand into Indonesia in early 2014 to control the invasive cassava mealybug, Phenacoccus manihoti Matile-Ferrero (Hemiptera: Pseudococcidae). Research was conducted in laboratory with the objectives to determine effect of honey on adult longevity, to study fecundity, progeny production, and sex ratio, and to evaluate effect of increased host density to parasitization. Studies were carried out by exposing $3^{\text {rd }}$ instar nymphs of mealybug to parasitoids. Effect of honey on adult longevity was done in the absence of hosts. Fecundity was measured by the number of mummies
\end{abstract}

\footnotetext{
*Penulis korespondensi: Juwita Suri Maharani. Departemen Proteksi Tanaman, Fakultas Pertanian, Institut Pertanian Bogor

Jalan Kamper, Kampus IPB Dramaga, Bogor 16680, Email: js.maharani77@gmail.com
} 
formed. Results showed that adult females lived for 3.7 days, while males lived for 3.2 days when only provided water. Adult longevity increased significantly when honey was provided. Parasitoids with access to $50 \%$ honey lived almost six to nine fold longer than those provided water. Over its adult life, A. lopezi parasitized 96-287 mealybugs with an average of 203.7 or $34.6 \%$ of hosts were parasitized, and $24.86 \%$ were killed through host feeding. Development from egg to adult emergence required 17.97 and 17.67 days for males and females respectively. The average number of offspring produced per female was 88.8 individuals, of which $56.9 \%$ were females. The number of hosts parasitized at densities varying from 2-100 cassava mealybugs corresponded to a type III functional response.

Key words: Anagyrus lopezi, cassava mealybug, parasitoid, Phenacoccus manihoti

\section{PENDAHULUAN}

Kutu putih singkong, Phenacoccus manihoti Matile-Ferrero (Hemiptera: Pseudococcidae), adalah hama asing invasif yang berasal dari Amerika Selatan. Hama ini pertama kali terdeteksi di Bogor pada tahun 2010 (Muniappan et al. 2011). Hingga akhir tahun 2014, kutu putih $P$. manihoti telah tersebar luas di Pulau Jawa dan Lampung (Abdulchalek et al. 2017) serta sejak tahun 2017 ditemukan di Pulau Flores (Pu'u 2019). Kutu P. manihoti bersifat monofag, hanya menyerang tanaman singkong (Cox \& Williams 1981). Berdasarkan wawancara dengan petani, serangan berat dapat menyebabkan kehilangan hasil panen singkong sebanyak 30-50\% (Wardani 2015).

Sebelum masuk ke Indonesia, kutu putih $P$. manihoti telah terlebih dahulu masuk ke Afrika pada awal tahun 1970-an (Nwanze 1982), dan selanjutnya masuk ke Asia (Thailand) pada tahun 2008 (Winotai et al. 2010). Parasitoid Anagyrus lopezi (De Santis) (Hymenoptera: Encyrtidae) diintroduksikan dari Brazil ke Afrika pada tahun 1981 untuk mengendalikan hama tersebut, (Herren \& Neuenschwander 1991). Selanjutnya, parasitoid A. lopezi dintroduksikan ke Thailand pada tahun 2010 (Lefroy 2010). Sebagai respons terhadap serangan $P$. manihoti, parasitoid $A$. lopezi juga kemudian diintroduksikan ke Indonesia pada awal tahun 2014 (Wyckhuys et al. 2014).

Pengendalian kutu $P$. manihoti di Afrika dengan introduksi parasitoid $A$. lopezi merupakan salah satu tonggak sejarah keberhasilan pengendalian hayati klasik (Neuenschwander 2001). Keberhasilan tersebut tidak lepas dari dukungan informasi dan pengetahuan yang dibangkitkan melalui penelitian kolaborasi dengan berbagai lembaga internasional. Cakupan kegiatan penelitian merentang dari pengembangan teknik pembiakan (Neuenschwander et al. 1989), biologi dan perilaku (Odebiyi \& Bokonon-Ganta 1986; Lohr et al. 1989; Umeh 1988), hingga evaluasi pelepasan parasitoid (Neuenschwander et al. 1986).

Mengacu pada keberhasilan di Afrika, pemanfaatan A. lopezi di Indonesia perlu didukung oleh kegiatan penelitian baik yang bersifat fundamental maupun terapan. Hingga kini belum banyak penelitian parasitoid A. lopezi yang sudah dilakukan di Indonesia, kecuali tentang kekhususan inang (Karyani et al. 2016) dan enkapsulasi (Adriani et al. 2016). Oleh karena itu, penelitian tentang berbagai aspek biologi dan ekologi $A$. lopezi kiranya perlu dilakukan. Pengetahuan tentang hal tersebut penting untuk dikuasai, tidak hanya untuk keperluan pembiakan massal (Goncalves et al. 2016) dan pelepasan parasitoid, tetapi juga untuk memahami ekologi populasi dan pengaruhnya terhadap hama sasaran di lapangan. Penelitian ini bertujuan memperkaya pemahaman tentang biologi $A$. lopezi dengan penekanan pada (1) pengaruh pemberian madu terhadap masa hidup imago, (2) keperidian, banyaknya progeni, nisbah kelamin, tingkat kematian inang, serta (3) pengaruh kerapatan inang terhadap tingkat parasitisasi. Informasi yang dihasilkan dari penelitian ini dapat memberikan sumbangan terhadap pemahaman yang lebih baik tentang peranan $A$. lopezi dalam pengendalian hayati kutu putih singkong.

\section{BAHAN DAN METODE}

Penelitian dilaksanakan sejak bulan Agustus 2016 hingga Juni 2017 di Laboratorium Bionomi dan Ekologi Serangga, Departemen Proteksi Tanaman, Fakultas Pertanian, Institut Pertanian Bogor (IPB). Selama penelitian berlangsung 
rata-rata suhu harian $\pm 27{ }^{\circ} \mathrm{C}$ dan kelembapan relatif $\pm 60 \%$. Perbanyakan kutu $P$. manihoti menggunakan bibit singkong, sedangkan untuk percobaan parasitisasi digunakan kutu putih yang dipelihara pada bibit ginseng (Talinum triangulare Willd). Bibit ginseng digunakan sebagai tanaman inang karena berukuran kecil dan daunnya tidak mudah layu.

\section{Penyiapan tanaman inang}

Stek singkong varietas Manggu diperoleh dari lahan petani di Kelurahan Cimahpar, Kecamatan Bogor Utara, Bogor. Stek sepanjang $\pm 20 \mathrm{~cm}$ kemudian dimasukkan ke dalam ember plastik yang berisi air dan pupuk cair, dan dibiarkan tumbuh hingga muncul daun. Stek ginseng diperoleh dari lahan di sekitar Kampus IPB Dramaga, Bogor, dan selanjutnya ditanam pada media tanah pada polybag berukuran $25 \mathrm{~cm} \times 25 \mathrm{~cm}$.

\section{Perbanyakan P. manihoti}

Kutu $P$. manihoti diperbanyak dengan cara seperti yang dilakukan oleh Adriani et al. (2016). P. manihoti yang berasal dari ruang pemeliharaan diinfestasikan pada tanaman singkong yang berumur \pm 3 minggu. Perbanyakan kutu putih dilakukan dalam kurungan serangga berukuran $100 \mathrm{~cm} \times 50 \mathrm{~cm}$ x $120 \mathrm{~cm}$ dengan sisi-sisi berbahan mika dan kain organdi. Sekitar 3-4 minggu setelah infestasi, nimfa instar-3 dikumpulkan untuk digunakan dalam pengujian.

\section{Perbanyakan parasitoid $A$. lopezi}

Perbanyakan parasitoid mengikuti cara yang dilakukan oleh peneliti sebelumnya (Karyani et al. 2016; Adriani et al. 2016). Imago A. lopezi dimasukkan ke dalam kurungan berisi tanaman singkong yang telah terinfestasi $P$. manihoti. Kurungan yang digunakan berukuran $50 \mathrm{~cm} \mathrm{x}$ $45 \mathrm{~cm} \times 45 \mathrm{~cm}$ dengan pintu berlapis kain kasa berukuran $15 \mathrm{~cm} \times 15 \mathrm{~cm}$ dengan dinding terbuat dari kain kasa dan plastik. Di dalam kurungan digantungkan kapas yang mengandung larutan madu $10 \%$. Setiap dua minggu sekali, tanaman singkong yang telah mengering dikeluarkan dan diganti dengan tanaman baru yang telah diinfestasi P. manihoti. Daun dan ranting tanaman singkong yang telah kering dan terdapat mumi kutu putih $P$. manihoti kemudian dipotong dari batang, lalu dimasukkan ke dalam kotak plastik yang ditutup kain kasa berukuran $20 \mathrm{~cm}$ x $25 \mathrm{~cm}$. Kurungan diletakkan di dalam ruangan khusus dengan suhu ruang $\pm 27{ }^{\circ} \mathrm{C}$, RH $60 \%$ dan berada di bawah penyinaran dua lampu neon 70 watt berjarak sekitar $20 \mathrm{~cm}$ di atas kurungan. Lama penyinaran 12 jam gelap dan 12 jam terang.

\section{Pengaruh madu terhadap masa hidup imago parasitoid}

Mumi P. manihoti yang berasal dari kurungan perbanyakan parasitoid, dikumpulkan dan kemudian secara individu dimasukkan ke dalam kapsul gelatin. Kemunculan imago parasitoid dari mumi diamati setiap hari. Sepasang imago parasitoid yang baru muncul dimasukkan ke dalam tabung plastik $(\mathrm{t}=15 \mathrm{~cm}, \mathrm{~d}=10 \mathrm{~cm})$ yang telah diberi lubang di bagian samping. Pada lubang tersebut dimasukkan kapas yang telah diberi perlakuan, yaitu air, larutan madu $10 \%, 50 \%$, dan $100 \%$, serta kontrol (tanpa diberi air atau madu). Pemberian pakan dilakukan setiap hari dengan menggunakan pipet tetes dan masing-masing diberikan sebanyak $0,25 \mathrm{ml}$. Setiap perlakuan diulang sebanyak 10 kali. Pengamatan dilakukan setiap hari, banyaknya parasitoid yang mati dan masih hidup dicatat.

\section{Keperidian dan progeni parasitoid serta mortalitas inang}

Sebanyak 20 individu nimfa $P$. manihoti instar-3 diinfestasikan pada bibit ginseng. Bagian pangkal bibit selanjutnya dimasukkan ke dalam tabung mika $(\mathrm{t}=20 \mathrm{~cm}, \mathrm{~d}=10 \mathrm{~cm})$, yang memiliki penutup pada bagian atasnya. Penutup diberi lubang berukuran $4 \mathrm{~cm}$ x $4 \mathrm{~cm}$ dan ditutup kain organdi. Imago parasitoid jantan dan betina yang berumur 1 hari dimasukkan ke dalam tabung selama 24 jam agar meletakkan telur pada kutu putih. Parasitoid diberi larutan madu 50\% yang dioleskan pada lembaran mika $(\mathrm{p}=2 \mathrm{~cm}, 1=2 \mathrm{~cm})$ yang ditempatkan di bagian dasar tabung mika. Setelah 24 jam parasitoid dipindahkan ke tabung baru yang di dalamnya terdapat tanaman ginseng dengan 20 individu nimfa $P$. manihoti instar-3, demikian seterusnya hingga imago betina parasitoid mati. Tujuh hari sejak kutu putih dipajankan pada parasitoid, mumi yang terbentuk dihitung dan kemudian masing-masing dimasukkan ke dalam kapsul gelatin. Imago parasitoid yang muncul dari mumi dicatat setiap hari dan dibedakan jenis 
kelaminnya. Selain itu, kutu putih yang mati karena mengalami pengisapan inang (host-feeding) oleh imago parasitoid dihitung dan dicatat. Kutu yang mati demikian biasanya dicirikan oleh tubuh yang mengerut. Percobaan menggunakan 10 pasang imago A. lopezi sebagai ulangan.

\section{Pengaruh kerapatan inang terhadap parasitisasi}

Kutu putih P. manihoti instar-3 diinfestasikan pada sehelai daun ginseng yang ujung tangkai daunnya diberi kapas berair agar tidak cepat layu. Perlakuan kerapatan kutu putih yang diuji adalah 2, 5, 10, 20, 50, dan 100 individu. Setiap perlakuan dilakukan dalam cawan petri $(\mathrm{d}=8,5$ $\mathrm{cm}$ ) yang telah diberi lubang berukuran $4 \mathrm{~cm} \mathrm{x}$ $4 \mathrm{~cm}$ pada bagian atas dan ditutup dengan kain organdi. Imago betina $A$. lopezi yang sudah kawin kemudian dimasukkan ke dalam cawan petri dan diberi pakan larutan madu 10\% yang diresapkan pada kapas. Setelah 24 jam imago A. lopezi dikeluarkan. Kutu putih yang menjadi mumi dimasukkan ke dalam kapsul gelatin. Imago yang muncul dari mumi diamati setiap hari. Masingmasing perlakuan diulang sebanyak 10 kali.

\section{Analisis data}

Analisis ragam dilakukan untuk memeriksa pengaruh pemberian larutan madu terhadap masa hidup imago dan pengaruh kerapatan inang terhadap tingkat parasitisasi, yang dilanjutkan dengan uji Tukey pada taraf 5\%. Seluruh pengolahan data dilakukan dengan menggunakan IBM SPSS Statistics 22. Hubungan antara tingkat parasitisasi dan kerapatan inang didekati dengan persamaan Gompertz sebagai berikut (Hyams 2010):

$$
\mathrm{Na}=\mathrm{P}_{1} \exp \left\{-\exp \left(\mathrm{P}_{2}-\mathrm{P}_{3} \mathrm{No}\right)\right\} \text {, dengan }
$$

No: kerapatan inang; Na: banyaknya inang yang terparasit; $\mathrm{P}_{1}$ : asimtot; $\mathrm{P}_{2}$ : posisi kurva sepanjang aksis $\mathrm{x}$; dan $\mathrm{P}_{3}$ : laju kurva menuju asimtot. Ketiga parameter tersebut diduga dengan bantuan program CurveExpert 1.4 (Hyams 2010).

\section{HASIL}

\section{Pengaruh madu terhadap masa hidup dan sintasan imago}

Masa hidup imago parasitoid yang diberi perlakuan air tidak berbeda nyata dengan perlakuan kontrol, yaitu sekitar 1-4 hari (Tabel 1). Pemberian larutan madu berpengaruh nyata terhadap masa hidup imago jantan $\left(\mathrm{F}_{4,45}=79,07\right.$; $\mathrm{P}<0,001)$ dan betina parasitoid A. lopezi $\left(\mathrm{F}_{4,45}=\right.$ $66,79 ; \mathrm{P}<0,001)$. Imago jantan yang diberi perlakuan madu $10 \%$ dapat hidup sekitar 24 hari, dan tidak berbeda nyata dengan yang diberi madu $50 \%$ dan $100 \%$. Imago betina yang diberi madu 100\% dapat hidup sekitar 36 hari, dan berbeda nyata dengan yang diberi madu 10\% (27 hari).

Kurva sintasan imago betina dan jantan $A$. lopezi yang diberi perlakuan berbeda disajikan pada Gambar 1. Tampak bahwa kurva sintasan parasitoid A. lopezi menurun tajam pada perlakuan air dan kontrol. Pada perlakuan larutan madu 10\%, $50 \%$, dan $100 \%$ kurva sintasan memperlihatkan tipe I, yaitu mortalitas terjadi pada individuindividu yang berumur tua. Dengan demikian, bila tersedia madu atau nektar maka imago betina parasitoid diperkirakan umumnya mati setelah menyelesaikan masa oviposisinya.

\section{Keperidian dan progeni parasitoid serta mortalitas inang}

Berdasarkan mumi yang terbentuk, satu imago betina parasitoid dapat menghasilkan telur sebanyak 203,7 butir, dengan kisaran 96-287 butir (Tabel 2). Namun demikian, tidak semua

Tabel 1. Masa hidup imago parasitoid Anagyrus lopezi pada berbagai perlakuan pakan

\begin{tabular}{lcc}
\hline \multirow{2}{*}{ Perlakuan } & \multicolumn{2}{c}{ Umur imago (hari) $^{1}$} \\
\cline { 2 - 3 } & \multicolumn{1}{c}{ Jantan } & Betina \\
\hline Kontrol & $1,60 \pm 0,31 \mathrm{a}$ & $1,60 \pm 0,22 \mathrm{a}$ \\
Air & $3,20 \pm 0,29 \mathrm{a}$ & $3,70 \pm 0,54 \mathrm{a}$ \\
Madu $10 \%$ & $23,90 \pm 1,85 \mathrm{~b}$ & $27,50 \pm 2,90 \mathrm{~b}$ \\
Madu $50 \%$ & $21,10 \pm 1,71 \mathrm{~b}$ & $32,10 \pm 2,64 \mathrm{bc}$ \\
Madu $100 \%$ & $24,20 \pm 1,30 \mathrm{~b}$ & $35,80 \pm 2,02 \mathrm{c}$ \\
\hline
\end{tabular}

${ }^{1}$ Nilai pada kolom yang sama yang diikuti huruf yang sama tidak menunjukkan beda nyata (Uji Tukey $\alpha=5 \%$ ). 
mumi menghasilkan imago parasitoid. Banyaknya imago keturunan yang muncul berkisar antara 30-237 individu, dengan rataan 89 individu dan nisbah kelamin $57 \%$ betina (Tabel 2). Gambar 2 menyajikan kemunculan harian dari imago keturunan menurut umur imago induk. Tampak bahwa imago induk yang berumur 1 hari sudah menghasilkan keturunan. Hal ini menunjukkan bahwa masa praoviposisi sangat singkat, yaitu kurang dari 24 jam. Puncak oviposisi terjadi pada umur 2-4 hari dengan keturunan sebanyak 6-7 individu per hari.

Dari 20 individu kutu putih yang dipajankan per hari terhadap parasitoid, tingkat parasitisasi berkisar antara $11-56 \%$ dengan rataan 35\% (Tabel 2). Selain karena diparasit, kematian inang juga disebabkan oleh pengisapan inang (host-feeding),

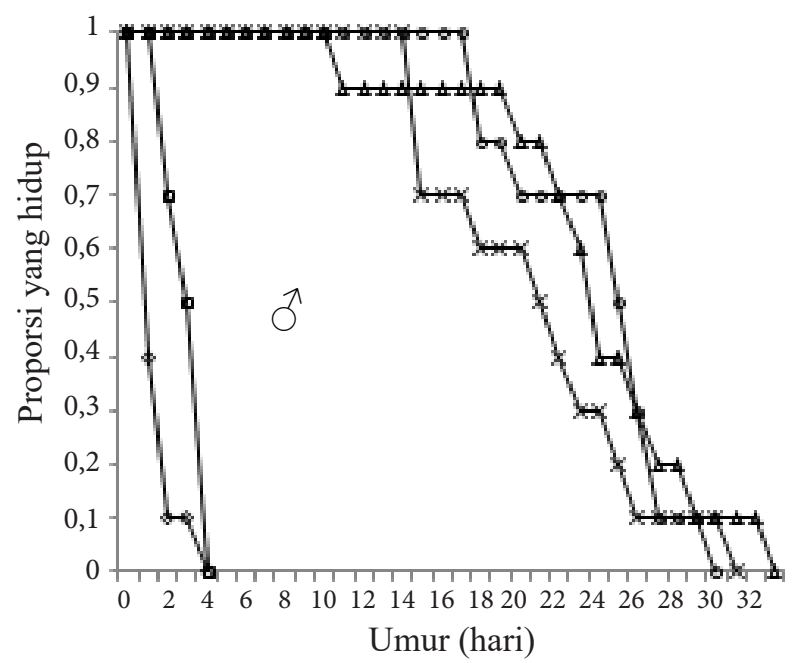

yaitu kegiatan penusukan ovipositor yang dilanjutkan dengan pengisapan cairan inang oleh imago parasitoid. Kematian karena pengisapan inang berkisar antara 58-242 dengan rataan 157,7 individu atau sekitar 25\% (Tabel 2). Berdasarkan waktu kemunculan imago dapat ditentukan masa perkembangan pradewasa, yaitu jantan berkisar antara 7-40 hari dengan rataan 17,97 hari, sedangkan betina berkisar 8-39 hari dengan rataan 17,67 hari (Gambar 3).

\section{Pengaruh kerapatan inang terhadap para- sitisasi}

Peningkatan kerapatan inang berpengaruh nyata terhadap banyaknya inang yang terparasit $(\mathrm{F}=11,89 ; \mathrm{db}=5,52 ; \mathrm{P}<0,001)$ serta terhadap tingkat parasitisasi $(\%)(\mathrm{F}=9,92 ; \mathrm{db}=5,54$;

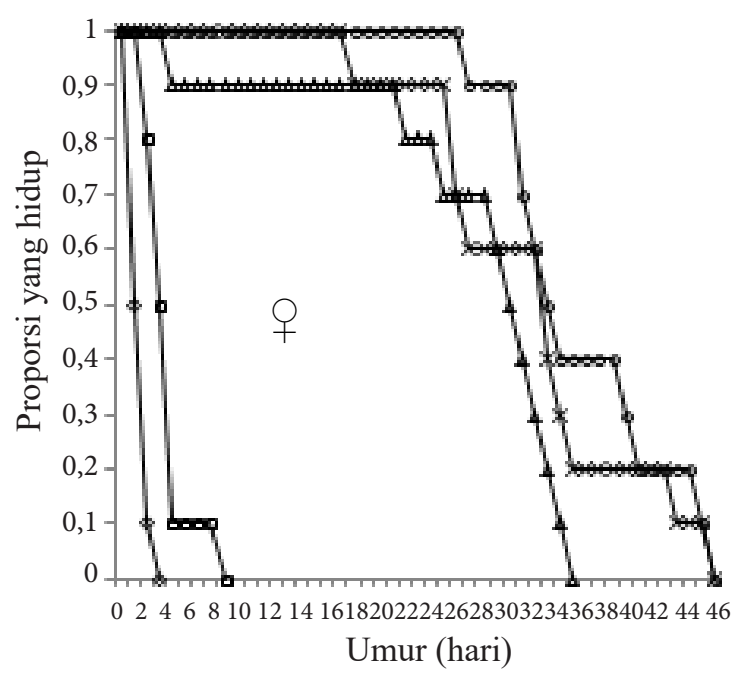

Gambar 1. Kurva sintasan harian imago parasitoid jantan dan betina Anagyrus lopezi. $\rightarrow \longrightarrow$ : kontrol; $\rightarrow \longrightarrow$ : air; $\longrightarrow$ : madu $10 \%$; $\rightarrow$ : madu 50\%; dan $\rightarrow$ : madu $100 \%$.

Tabel 2. Masa hidup imago, progeni, dan nisbah kelamin parasitoid Anagyrus lopezi

\begin{tabular}{lccccccc}
\hline $\begin{array}{l}\text { No } \\
\text { imago }\end{array}$ & $\begin{array}{c}\text { Masa hidup } \\
\text { (hari) }\end{array}$ & $\begin{array}{c}\Sigma \text { Mumi } \\
\text { (individu) }\end{array}$ & $\begin{array}{c}\text { Tingkat } \\
\text { parasitisasi } \\
(\%)\end{array}$ & $\begin{array}{c}\text { Kematian karena } \\
\text { pengisapan inang } \\
\text { (individu) }\end{array}$ & $\begin{array}{c}\text { Tingkat } \\
\text { pengisapan inang } \\
(\%)\end{array}$ & $\begin{array}{c}\text { Progeni } \\
\text { muncul } \\
\text { (individu) }\end{array}$ & $\begin{array}{c}\text { Persentase } \\
\text { betina } \\
(\%)\end{array}$ \\
\hline 1 & 35 & 259 & 37,0 & 207 & 29,57 & 237 & 60,76 \\
2 & 26 & 269 & 51,7 & 128 & 24,62 & 172 & 60,47 \\
3 & 23 & 258 & 56,1 & 58 & 12,61 & 162 & 59,26 \\
4 & 24 & 112 & 23,3 & 147 & 30,63 & 37 & 72,97 \\
5 & 41 & 96 & 11,7 & 242 & 29,51 & 37 & 45,95 \\
6 & 41 & 119 & 14,5 & 225 & 27,44 & 68 & 48,53 \\
7 & 25 & 110 & 22,0 & 183 & 36,60 & 54 & 57,41 \\
8 & 40 & 287 & 35,9 & 169 & 21,13 & 57 & 57,89 \\
9 & 24 & 269 & 56,0 & 78 & 16,25 & 34 & 55,88 \\
10 & 34 & 258 & 37,9 & 138 & 20,29 & 30 & 50,00 \\
\hline Rataan & 31,3 & 203,7 & 34,6 & 157,5 & 24,86 & 88,8 & 56,91 \\
\hline
\end{tabular}




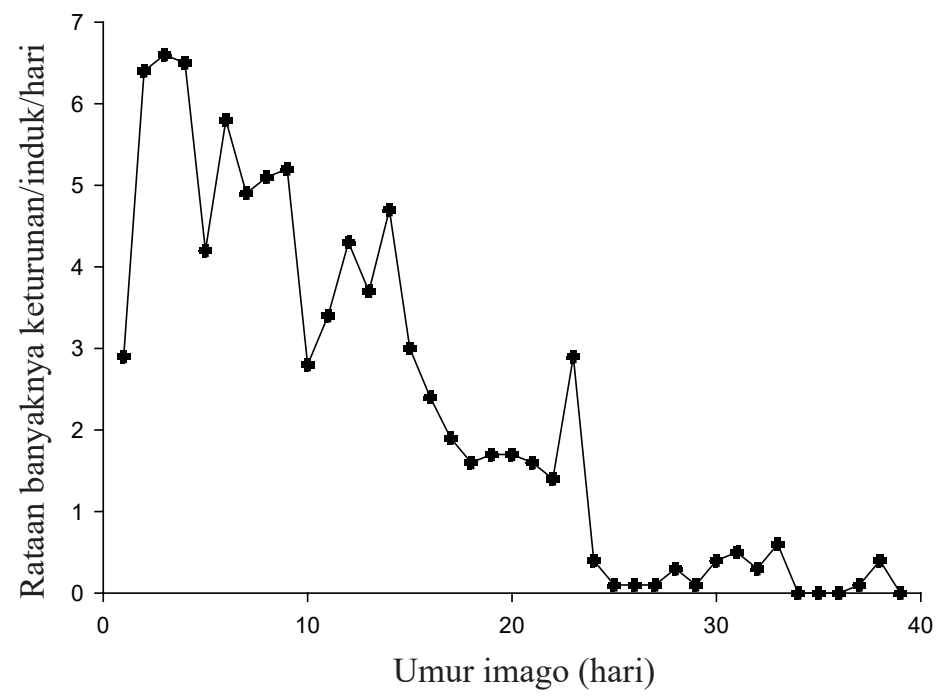

Gambar 2. Rataan banyaknya imago keturunan parasitoid Anagyrus lopezi yang muncul per hari.
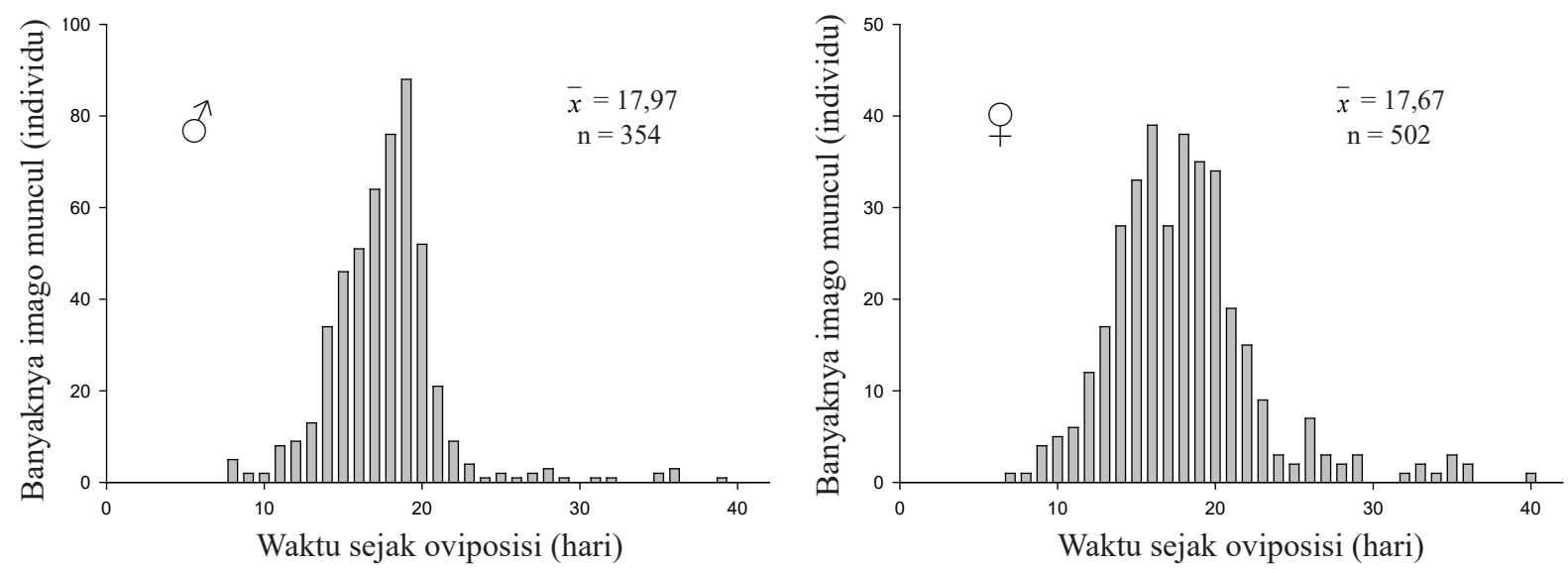

Gambar 3. Frekuensi kemunculan imago parasitoid jantan dan betina Anagyrus lopezi.

$\mathrm{P}<0$,001) (Tabel 3). Kurva proporsi inang yang terparasit memperlihatkan pola peningkatan pada kerapatan inang rendah dan kemudian menurun (Gambar 4). Hal ini mengindikasikan tanggap fungsional tipe III. Hubungan antara banyaknya inang terparasit dan peningkatan kerapatan inang menurut persamaan Gompertz disajikan pada Gambar 5. Tampak bahwa banyaknya inang yang terparasit meningkat pada kerapatan 2 hingga 30 inang, dan setelah itu kurva mulai melandai.

\section{PEMBAHASAN}

Makanan merupakan faktor penting yang menentukan masa hidup dan sintasan parasitoid. Pemberian larutan madu 50\% dapat meningkatkan masa hidup imago parasitoid $A$. lopezi sebanyak 6-9 kali lipat lebih lama dibandingkan dengan yang hanya diberi air. Hasil ini sejalan dengan penelitian lainnya yang menunjukkan bahwa pemberian madu dapat memperpanjang masa hidup imago parasitoid Anagyrus kamali Moursi (Hymenoptera: Encyrtidae), parasitoid kutu putih Maconnelicoccus hirsutus (Green) (Hemiptera: Pseudococcidae) yang diberi madu hidup 20 kali lebih lama daripada yang tidak diberi madu (Sagarra et al. 2000b). Masa hidup imago parasitoid Blepyrus clavicornis (Compere) (Hymenoptera: Encyrtidae) berlangsung 33 hari pada ketersediaan madu, tetapi 4 hari pada perlakuan air (Pacheo da Silva et al. 2017). Gonzales-Hernandez et al. (2005) melaporkan imago betina Anagyrus ananatis Gahan (Hymenoptera: Encyrtidae), parasitoid kutu putih Dysmicoccus brevipes (Cockerell) (Hemiptera: Pseudococcidae), hidup selama 21-31 hari bila disediakan madu, sedangkan bila tanpa madu hidup jauh lebih singkat (3 hari). Pemberian madu, selain memperpanjang masa hidup imago, juga dapat meningkatkan keperidian 
Tabel 3. Parasitisasi Anagyrus lopezi pada berbagai kerapatan inang

\begin{tabular}{ccc}
\hline $\begin{array}{l}\text { Banyaknya inang yang tersedia } \\
\text { (individu) }\end{array}$ & $\begin{array}{c}\text { Banyaknya inang yang terparasit } \\
\text { (individu) }\end{array}$ & \begin{tabular}{c} 
Tingkat parasitisasi $_{(\%)}$ \\
\hline 2
\end{tabular} \\
5 & $3,62 \pm 0,18 \mathrm{a}$ & $65,00 \pm 13,00 \mathrm{a}$ \\
10 & $3,70 \pm 0,34 \mathrm{ab}$ & $74,00 \pm 6,70 \mathrm{a}$ \\
20 & $7,30 \pm 0,59 \mathrm{ab}$ & $73,00 \pm 5,97 \mathrm{a}$ \\
50 & $10,20 \pm 1,36 \mathrm{bc}$ & $51,00 \pm 6,82 \mathrm{ab}$ \\
100 & $16,70 \pm 2,72 \mathrm{c}$ & $33,40 \pm 5,44 \mathrm{bc}$ \\
\hline
\end{tabular}

${ }^{1}$ Nilai pada kolom yang sama yang diikuti huruf yang sama tidak menunjukkan beda nyata (Uji Tukey $\alpha=5 \%$ ).

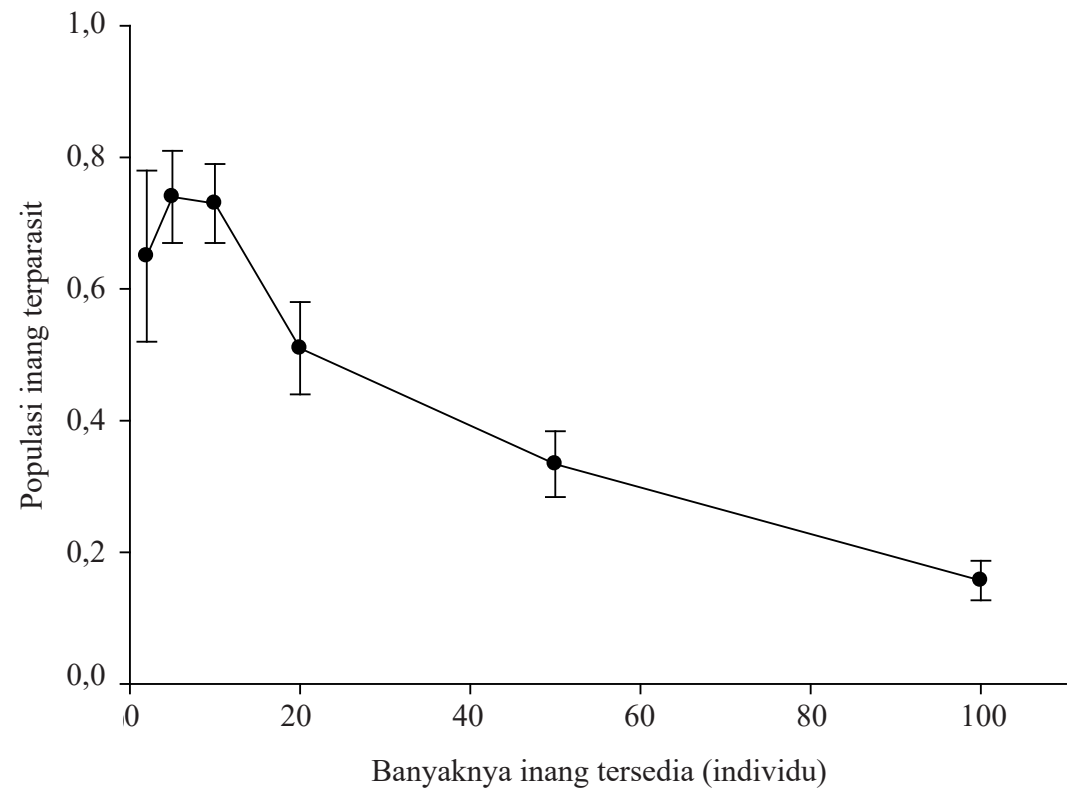

Gambar 4. Kurva proporsi kutu putih yang terparasit Anagyrus lopezi pada berbagai kerapatan inang.

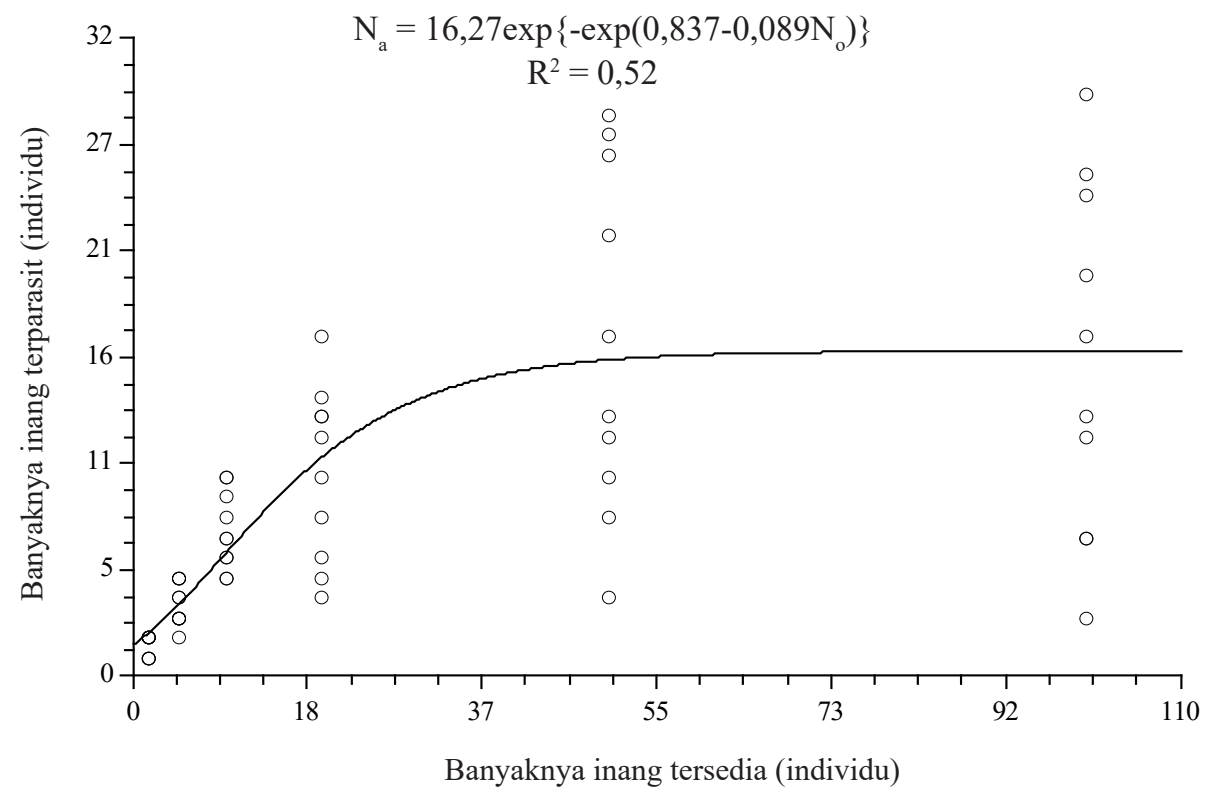

Gambar 5. Kurva tanggap fungsional parasitoid Anagyrus lopezi terhadap peningkatan kerapatan inang. 
pada parasitoid sinovigenik (Heimpel \& Collier 1996). Biassangamaetal.(1988)melaporkanbahwa parasitoid $A$. lopezi yang diberi madu meletakkan telur sebanyak 208 butir, sedangkan yang tanpa madu 140 butir. Parasitoid Bracon hebetor (Say.) (Hymenoptera: Braconidae) memiliki keperidian yang lebih banyak pada perlakuan madu 50\% dibandingkan dengan perlakuan kontrol (Ashraf et al. 2017). Karbohidrat merupakan sumber energi utama untuk kehidupan imago parasitoid serta produksi dan pematangan telur, khususnya parasitoid yang bersifat sinovigenik (Jervis et al. 2008). Selain itu, bertambahnya masa hidup imago akibat pemberian madu memungkinkan parasitoid berhasil sintas sampai menemukan inang yang sesuai (Hanan et al. 2010).

Dalam penelitian ini keperidian $A$. lopezi dihitung berdasarkan mumi yang terbentuk, yaitu setara 204 butir. Angka ini jauh lebih tinggi daripada yang dilaporkan oleh Odebiyi \& BokononGanta (1986), Umeh (1988), dan Lohr et al. (1989), yaitu berturut-turut 67, 34, dan 84 butir; namun hampir sama dengan yang dilaporkan oleh Biassangama et al. (1988), yaitu 208 butir. Penentuan keperidian yang didasarkan pada mumi yang terbentuk atau imago parasitoid yang muncul mengasumsikan bahwa parasitoid hanya meletakkan satu butir telur per inang. Dilaporkan bahwa superparasitisme umum terjadi pada parasitoid A. lopezi (van Dijken et al. 1993). Adriani et al. (2016) melaporkan bahwa sekitar $30 \%$ dari kutu $P$. manihoti yang terparasit di dalam tubuhnya terdapat 2 atau lebih telur $A$. lopezi. Oleh karena itu, banyaknya telur yang diletakkan dapat jauh lebih banyak daripada mumi yang terbentuk atau imago yang muncul. Dengan melakukan diseksi inang, Iziquel \& Le Ru (1992) mendapatkan keperidian sebanyak 559 butir telur.

Masa perkembangan pradewasa $A$. lopezi dipengaruhi oleh fase perkembangan atau instar inang. Dengan menggunakan nimfa instar-3 sebagai inang dan pada suhu $27{ }^{\circ} \mathrm{C}$, masa perkembangan pradewasa sejak telur hingga imago muncul memerlukan waktu 18 hari. Angka yang sama diperoleh Odebiyi \& Bokonon-Ganta (1986) yang melakukan penelitian $A$. lopezi dengan menggunakan nimfa instar-3 dan suhu $27{ }^{\circ} \mathrm{C}$. Sementara Umeh (1988), pada kisaran suhu 26$34{ }^{\circ} \mathrm{C}$, melaporkan bahwa masa perkembangan pradewasa A. lopezi 19, 17, 16, dan 15 hari berturut-turut pada nimfa instar-1, -2, -3, dan -4 . Suhu ruang pemeliharaan juga dapat memengaruhi masa perkembangan pradewasa. Pada suhu $30{ }^{\circ} \mathrm{C}$ masa perkembangan pradewasa $A$. lopezi berlangsung selama 16 hari, sedangkan pada suhu $20^{\circ} \mathrm{C}$ berlangsung selama 43 hari (Lohr et al. 1989).

Parasitoid A. lopezi tergolong arenotoki, yaitu induk yang kawin menghasilkan progeni jantan dan betina. Sebanyak $57 \%$ dari progeni yang dihasilkan adalah betina. Lebih tingginya proporsi betina pada $A$. lopezi juga dilaporkan oleh peneliti lainnya (Lohr et al. 1989; Umeh 1988; Odebiyi \& Bokonon-Ganta 1986). Nisbah kelamin dari progeni yang muncul dapat dipengaruhi oleh kualitas inang. Kraaijeveld \& van Alphen (1986) melaporkan parasitoid A. lopezi yang muncul dari kutu putih nimfa instar-3 terdiri atas $82 \%$ betina, sedangkan yang berasal dari instar-2 semuanya jantan. Umumnya parasitoid memilih inang yang berukuran kecil untuk peletakan telur bakal jantan, sementara inang yang berukuran besar untuk telur bakal betina (Godfray 1994).

Kematian kutu putih P. manihoti, selain karena terparasit, juga terjadi karena pengisapan inang oleh imago parasitoid. Hal ini karena parasitoid A. lopezi bersifat sinovigenik (Iziquel \& Le Ru 1992) yang perlu mengonsumsi hemolimfa inang sebagai sumber protein untuk pematangan telur dan perpanjangan masa produksi telur (Heimpel \& Collier 1996). Berbagai studi menunjukkan bahwa terdapat hubungan linear positif antara pengisapan inang dengan keperidian dan masa hidup imago parasitoid (Heimpel \& Collier 1996). Neuenschwander \& Madojemu (1986) melaporkan bahwa kegiatan pengisapan inang lebih sering terjadi pada kutu putih instar-1 dan instar-2 dibandingkan dengan instar lanjut. Oleh karena itu, walaupun tingkat parasitisasi di lapangan jarang melebihi 30\% (Lema \& Herren 1985), kematian kutu putih dapat lebih tinggi sebagai akibat dari perilaku pengisapan inang (Neuenschwander \& Sullivan 1987). Menurut Neuenschwander \& Madojemu (1986) mortalitas karena pengisapan inang merupakan komponen utama dari keefektifan $A$. lopezi sebagai agens pengendalian hayati P. manihoti.

Dari rataan 204 mumi yang terbentuk, sebanyak 88 mumi atau $44 \%$ menghasilkan imago parasitoid A. lopezi. Angka ini jauh lebih rendah daripada 
yang dilaporkan (94\%) oleh Lohr et al. (1989) untuk spesies yang sama pada suhu laboratorium yang sama $\left(27^{\circ} \mathrm{C}\right)$. Tidak diketahui dengan pasti penyebab perbedaan ini, tetapi Kraaijeveld \& van Alphen (1986) melaporkan terjadinya kematian parasitoid setelah inang mengalami mumifikasi. Mumi yang tidak menghasilkan imago parasitoid mungkin karena kematian inang bukan oleh parasitisasi, tetapi karena mekaniame lain, seperti pseudoparasitisme atau aborsi parasitisme (aborted parasitism) (Abram et al. 2019).

Hubungan antara tingkat parasitisasi dan kerapatan inang menentukan tipe tanggap fungsional, yang pada giliran berikutnya menentukan dinamika populasi parasitoid dan inang, serta kestabilan sistem parasitoid-inang (Hassell et al. 1977). Hasil studi menunjukkan bahwa parasitoid $A$. lopezi memperlihatkan tanggap fungsional tipe III terhadap peningkatan kerapatan kutu putih $P$. manihoti. Hasil yang sama dilaporkan oleh Sagarra et al. (2000a) yang meneliti tanggap fungsional $\mathrm{A}$. kamali pada $M$. hirsutus. Sementara, Chong \& Oeting (2006) melaporkan tanggap fungsional tipe II pada parasitoid Anagyrus sp. nov. nr. sinope Noyes \& Menezes (Hymenoptera: Encyrtidae) yang memarasit kutu putih Phenacoccus madeirensis Green (Hemiptera: Pseudococcidae). Tanggap fungsional tipe II juga diperlihatkan oleh parasitoid Aenasius bambawalei Hayat yang memarasit kutu putih Phenacoccus solenopsis Tinsley (Feng et al. 2014; Joodaki et al. 2018). Berbagai studi tanggap fungsional parasitoid menunjukkan bahwa lebih dari tiga perempatnya memperlihatkan tanggap fungsional tipe II, sedangkan seperlimanya memperlihatkan tipe III (Fernandez-Arhex \& Corley 2003).

Tanggap fungsional tipe III umumnya diperlihatkan oleh predator golongan vertebrata yang memiliki kemampuan belajar dari pengalaman dalam menemukan mangsa (Fujii et al. 1986). Menurut Hassell et al. (1977) predator dari golongan invertebrata juga dapat memperlihatkan tanggap fungsional tipe III. Dilaporkan bahwa parasitoid memiliki kemampuan untuk memelajari penciri (cue) dari inang dan menggunakannya dalam proses penemuan inang berikutnya (Turlings et al. 1993). Dalam hal ini diduga bahwa parasitoid A. lopezi mampu membedakan kutu putih yang 146 telah terparasit dan belum sehingga menghasilkan tanggap fungsional tipe III.

Berdasarkan kurva tanggap fungsional tipe III (persamaan Gompertz), maksimum banyaknya kutu putih $P$. manihoti yang dapat diparasit oleh A. lopezi per hari sekitar 16 individu. Selain karena diparasit, kematian inang dapat lebih besar karena adanya perilaku pengisapan inang oleh imago parasitoid, seperti disebutkan sebelumnya. Menurut Jervis et al. (1996) parasitoid yang melakukan pengisapan inang merupakan agens hayati yang lebih baik karena mampu memberikan tambahan kematian pada inang.

Keseluruhan hasil penelitian menawarkan implikasi praktis bagi pemanfaatan parasitoid $A$. lopezi sebagai agens pengendalian hayati kutu $P$. manihoti. Hasil penelitian menunjukkan bahwa pemberian larutan madu dapat meningkatkan masa hidup imago betina dan jantan A. lopezi. Oleh karena itu, penyediaan madu menjadi sangat penting dalam kaitan dengan pengiriman parasitoid antar negara, atau bahkan antar pulau atau kota. Penyediaan madu selama di perjalanan dapat menjamin seluruh atau sebagian besar parasitoid berhasil sintas sampai di tempat tujuan.

Keberhasilan parasitoid menetap di tempat baru bergantung pada kondisi fisiologis dari individu parasitoid yang dilepas serta perilaku pencarian inang oleh parasitoid pascapelepasan (Mills \& Wajnberg 2008). Sebelum dilepas ke lapangan, parasitoid biasanya ditempatkan pada wadah yang diberi larutan madu, tetapi tanpa inang kutu putih sehingga tidak dapat melakukan pengisapan inang dan oviposisi. Hingga kini belum tersedia informasi tentang pengaruh ketiadaan pakan (madu) dan inang terhadap kegiatan oviposisi dan pengisapan inang oleh parasitoid A. lopezi. Pada parasitoid Encarsia sophia Girault \& Dodd dan Eretmocerus melanoscutus Zolnerowich \& Rose (Hymenoptera: Aphelinidae), ketiadaan pakan (madu) dan inang selama 6 jam meningkatkan tingkat pengisapan inang dan parasitisasi serta masa hidup imago (Zang \& Liu 2009; Zang \& Liu 2010). Begitu pula Hanan et al. (2015) melaporkan ketiadaan pakan dan inang selama 5 jam meningkatkan pengisapan inang, parasitisasi, dan masa hidup imago Eretmocerus warrae (Naumann \& Schimdt), parasitoid kutu kebul Trialeurodes vaporariorum (Westwood). Hal 
berbeda terjadi pada Tamarixia radiata (Waterston) (Hymenoptera: Eulophidae), parasitoid dari kutu loncat Diaphorina citri Kuwayama, ketiadaan inang selama 3 hari menurunkan parasitisasi (Tena et al. 2017). Dalam kaitan ini, kiranya perlu dilakukan penelitian tentang pengaruh ketiadaan pakan dan inang terhadap tingkat parasitisasi dan pengisapan inang oleh $A$. lopezi. Berdasarkan hasil penelitian tersebut, tingkat parasitisasi diharapkan dapat ditingkatkan melalui penciptaan prakondisi yang meningkatkan kebugaran imago parasitoid yang akan dilepas.

Setelah berhasil menetap di lapangan, imago parasitoid dapat memanfaatkan nektar bunga, nektar ekstraflora, atau embun madu sebagai sumber karbohidrat (Begum et al. 2006). Irvin \& Hoddle (2015) melaporkan progeni parasitoid Anagyrus pseudococci (Girault) meningkat berturut-turut $132 \%$ dan $152 \%$ jika induk betina parasitoid disediakan nektar dari bunga soba (Fagopyrum esculentum Moench) dan ekstraflora dari tanaman Vicia sativa L. dibandingkan dengan yang hanya diberi air. Parasitoid Telenomus podisi Ashmead (Hymenoptera: Platygastridae) yang diberi embun madu dari kutu daun Aphis craccivora Koch (Hemiptera: Aphididae) memiliki masa hidup dan keperidian yang sama dengan yang diberi nektar bunga soba dan madu (Lahiri et al. 2017). Dengan demikian, pemahaman tentang kebutuhan nutrisi parasitoid merupakan hal penting dalam upaya penataan lanskap pertanian yang menunjang kehidupan parasitoid.

Hasil dari studi tanggap fungsional dapat digunakan untuk menilai potensi keefektifan parasitoid di dalam pengendalian hayati (van Lenteren et al. 2016). Hasil studi menunjukkan bahwa parasitoid $A$. lopezi memperlihatkan tanggap fungsional tipe III. Secara teoritis tanggap fungsional tipe III lebih memiliki kemampuan mengendalikan populasi hama dibandingkan dengan tipe II. Walaupun tanggap fungsional merupakan faktor penting untuk mengevaluasi potensi musuh alami, tetapi keberhasilan atau kegagalan musuh alami di dalam pengendalian hayati tidak hanya bergantung pada faktor ini (Fernandez-Arhex \& Corely 2003; Ebrahimifar et al. 2017). Menurut Joodaki et al. (2018) faktor lain, seperti faktor biotik dan abiotik dan tumbuhan inang dapat memengaruhi penemuan inang dan keefektifan parasitoid di dalam pengendalian hayati.

\section{KESIMPULAN}

Pemberian larutan madu 50\% meningkatkan masa hidup imago parasitoid 6-9 kali lipat lebih lama daripada yang hanya diberi air. Selama hidupnya, imago parasitoid betina mampu memarasit rata-rata 204 kutu putih P. manihoti, dan banyaknya imago progeni yang muncul 89 individu dengan nisbah kelamin $57 \%$ betina. Anagyrus lopezi merupakan parasitoid yang potensial karena mampu menyebabkan kematian pada kutu putih melalui parasitisasi sebesar $35 \%$ dan pengisapan inang 25\%. Parasitoid A. lopezi memperlihatkan tanggap fungsional tipe III terhadap peningkatan populasi kutu putih.

\section{DAFTAR PUSTAKA}

Abduchalek B, Rauf A, Pudjianto. 2017. Kutu putih singkong, Phenacoccus manihoti Matile-Ferrero (Hemiptera: Pseudococcidae): Persebaran geografi di Pulau Jawa dan rintisan pengendalian hayati. Jurnal Hama dan Penyakit Tumbuhan Tropika 17:1-8. doi: https://doi.org/10.23960/j. hptt.1171-8.

Abram PK, Brodeur J, Urbaneja A, Tena A. 2019. Nonreproductive effects of insect parasitoids on their hosts. Annual Review of Entomology 64:259-276. doi: https://doi.org/10.1146/ annurev-ento-011118-111753.

Adriani E, Rauf A, Pudjianto. 2016. Laju enkapsulasi parasitoid Anagyrus lopezi (De Santis) (Hymenoptera: Encyrtidae) oleh kutu putih singkong, Phenacoccus manihoti MatileFerrero (Hemiptera: Pseudococcidae). Jurnal Entomologi Indonesia 13:147-155. doi: https:// doi.org/10.5994/jei.13.3.147.

Ashraf S, Abidin Z, Abbas SK, Khan RSA, Tahir M, Rasool S, Anwar M, Hussain F. 2017. Effect of different diet concentrations on longevity and fecundity of parasitic wasp Bracon hebetor (Say.) (Hymenoptera: Braconidae). Pakistan Journal of Zoology 49:761-767. doi: https://doi. org/10.17582/journal.pjz/2017.49.3.761.767.

Begum M, Gurr GM, Wratten SD, Hedberg PR, Nicol HI. 2006. Using selective food plants to maximize 
biological control of vineyard pests. Journal of Applied Ecology 43:547-554. doi: https://doi. org/10.1111/j.1365-2664.2006.01168.x.

Biassangama A, Fabres G, Nenon JP. 1988. Parasitisme au laboratore et au champ D'Epidinocarsis (Apoanagyrus) lopezi (Hym: Encyrtidae) auxiliarie exotique introduit au Congo pour la regulation de I'abondance de Phenacoccus manihoti. Entomophaga 33:453465. doi: https://doi.org/10.1007/BF02373182.

Chong JH, Oetting RD. 2006. Functional response and progeny production of the Madeira mealybug parasitoid, Anagyrus sp. nov. nr. sinope: The effects of host and parasitoid densities. Biological Control 39:320-328. doi: https://doi. org/10.1016/j.biocontrol.2006.08.013.

Cox MJ, Williams DJ. 1981. An account of cassava mealybug (Hemiptera: Pseudococcidae) with a description of a new species. Bulletin of Entomological Research 71:247-458. doi: https://doi.org/10.1017/S0007485300008270.

Ebrahimifar J, Jamshidnia A, Allahyari H. 2017. Functional response of Eretmocerus delhiensis (Hymenoptera: Aphelinidae) on Trialeurodes vaporariorum (Hemiptera: Aleyrodidae) by parasitism and host feeding. Journal of Insect Science 17:1-5. doi: https://doi.org/10.1093/ jisesa/iex029.

Feng DD, Li P, Zhou ZS, Xu ZF. 2014. Parasitism potential of Aenasius bambawalei on the invasive mealybug Phenacoccus solenopsis. Biocontrol Science and Technology 24:1333-1338. doi: https://doi.org/10.1080/09583157.2014.939946.

Fernandez-Arhex V, Corley JC. 2003. The functional response of parasitoids and its implications for biological control. Biocontrol Science and Technology 13:403-413. doi: https://doi.org/10. 1080/0958315031000104523.

Fujii K, Holling CS, Mace PM. 1986. A simple generalized model attack by predators and parasities. Ecological Research 1:141-156. doi: https://doi.org/10.1007/BF02347017.

Godfray HCJ. 1994. Parasitoids, Behavioural and Evolutionary Ecology. New Jersey: Princeton University Press.

Goncalves RS, Andreazza F, Lisboa H, Grutzmacher AD, Valgas RA, Manica-Berto R, Nornberg SD, Nava DE. 2016. Basis for development of a rearing technique of Aganaspis pelleranoi (Hymenoptera: Figitidae) in Anastrepha fraterculus (Tephritidae: Diptera). Journal of Economic Entomology 109:1094-1101. doi: https://doi.org/10.1093/jee/tow069.
Gonzales-Hernandes H, Pandey RR, Johnson MW. 2005. Biological characteristics of adult Anagyrus anatatis Gahan (Hymenoptera: Encyrtidae), a parasitoid of Dysmicoccus brevipes (Cockerell) (Hemiptera: Pseudococcidae). Biocontrol 35:93-103. doi: https://doi.org/10.1016/j. biocontrol.2005.07.014.

Hanan A, He XZ, Shakeel M, Wang Q. 2010. Effect of food supply on reproductive potential of Eretmocerus warrae (Hymenoptera: Aphelinidae). New Zealand Plant Protection 63:113-117.

Hanan A, He XZ, Shakeel M, Khan J, Wang Q. 2015. Does certain host and food deprivation period affect host feeding and oviposition behavior of Eretmocerus warrae (Hymenoptera: Aphelenidae). Journal of Entomological Research Society 17:51-59. doi: https://doi. org/10.30843/nzpp.2010.63.6550.

Hassell MP, Lawton JH, Beddington JR. 1977. Sigmoid functional responses by invertebrate predators and parasitoids. Journal of Animal Ecology 46:249-262. https://doi. org/10.2307/3959.

Heimpel GE, Collier TR. 1996. The evolution of host-feeding behaviour in insect parasitoids. Biological Reviews 71:373-400. doi: https://doi. org/10.1111/j.1469-185X.1996.tb01279.x.

Herren HR, Neuenschwander P. 1991. Biological control of cassava pest in Africa. Annual Review of Entomology 36:257-83. doi: https://doi. org/10.1146/annurev.en.36.010191.001353.

Hyams DG. 2010. CurveExpert software. Tersedia di: http://www.curveexpert.net. [diakses 5 Agustus 2016].

Irvin NA, Hoddle MS. 2015. The effects of buckwheat flowers and cahaba vetch extrafloral nectaries on fitness of the vine mealybug parasitoid Anagyrus pseudococci (Hymenoptera: Encyrtidae). Florida Entomologist 98:237-242. doi: https:// doi.org/10.1653/024.098.0140.

Iziquel Y, Le Ru B. 1992. Fecundity, longevity, and intrinsic natural rate of increase of Epidinocarsis lopezi (De Santis) (Hymenoptera: Encyrtidae). Canadian Entomologist 124:1115-1121. doi: https://doi.org/10.4039/Ent1241115-6.

Jervis MA, Ellers J, Harvey JA. 2008. Resource acquisition, allocation, and utilization in parasitoid reproductive strategies. Annual Review of Entomology 53:361-385. doi: https://doi. org/10.1146/annurev.ento.53.103106.093433.

Jervis MA, Hawkins BA, Kidd NAC. 1996. The usefulness of destructive host feeding 
parasitoids in classical biological control: theory and observation conflict. Ecological Entomology 21:41-46. doi: https://doi. org/10.1111/j.1365-2311.1996.tb00264.x.

Joodaki R, Zandi-Sohani N, Zarghami S, Yarahmadi F. 2018. Temperature-dependent functional response of Aenasius bambawalei (Hymenoptera: Encyrtidae) to different population densities of the cotton mealybug Phenacoccus solenopsis (Hemiptera: Pseudococcidae). European Journal of Entomology 115:326-331. doi: https://doi. org/10.14411/eje.2018.032.

Karyani RD, Maryana N, Rauf A. 2016. Pengujian kekhususan inang parasitoid Anagyrus lopezi (De Santis) (Hymenoptera: Encyrtidae) pada empat spesies kutu putih yang berasosiasi dengan tanaman singkong. Jurnal Entomologi Indonesia 13:30-39. doi: https://doi.org/10.5994/ jei.13.1.30.

Kraaijeveld AR, van Alphen JJM. 1986. Host stage selection and sex allocation by Epidinocarsis lopezi (Hymenoptera: Encyrtidae), a parasitoid of the cassava mealybug, Phenacoccus manihoti (Homoptera: Pseudococcidae). Mededelingen Faculteit Landbouwwetenschappen Rijksuniversiteit Gent 51/3a:1067-1078.

Lahiri S, Orr D, Cardoza YJ, Sorenson C. 2017. Longevity and fecundity of the egg parasitoid Telenomus podisi provided with different carbohydrate diets. Entomologia Experimentalis et Applicata 162:178-187. doi: https://doi. org/10.1111/eea.12531.

Lefroy D. 2010. Cassava under threat: Pest and disease outbreaks put SE Asia on high alert. CIAT E-Newsletter No. 6. Tersedia pada: http:// www.fidafrique.net/article1908.html. [diunduh 5 Agustus 2016].

Lema KM, Herren HR. 1985. Release and establishment in Nigeria of Epidinocarcis lopezi, a parasitoid of the cassava mealybug, Phenacoccus manihoti. Entomologia Experimentalis et Applicata 38:171-175. doi: https://doi.org/10.1111/j.1570-7458.1985. tb03515.x.

Lohr B, Varela AM, Santos B. 1989. Life-table studies on Epidinocarsis Iopezi (De Santis) (Hym.: Encyrtidae), a parasitoid of the cassava mealybug, Phenacoccus manihoti Mat.-Ferr. (Hom.: Pseudococcidae). Journal of Applied Entomology 107:425-434. doi: https://doi. org/10.1111/j.1439-0418.1989.tb00279.x.

Mills NJ, Wajnberg E. 2008. Optimal foraging behavior and efficient biological control methods. Di dalam: Wajnberg E, van Alphen JJM, Bernstein C (Eds.), Behavioural Ecology of Insect Parasitoids: From Theoretical Approach to Field Applications. hlm. 3-30. Oxford: Blackwell.

Muniappan R, Shepard BM, Watson GW, Carner GR, Rauf A, Sartiami D, Hidayat P, Afun JVK, Goergen G, Rahman AKMZ. 2011. New records of invasive insects (Hemiptera: Sternorrhyncha) in Southern Asia and West Africa. Journal of Agricultural and Urban Entomology 26:167174. doi: https://doi.org/10.3954/1523-547526.4.167.

Neuenschwander P. 2001. Biological control of the cassava mealybug in Africa: A review. Biological Control 21:214-229. doi: https://doi. org/10.1006/bcon.2001.0937.

Neuenschwander P, Haug T, Ajounu O, Davis H, Akinwumi B, Madojemu E. 1989. Quality requirements in natural enemies used for inoculative release: Practical experience from a successful biological control programme. Journal of Applied Entomology 108:409-420. doi: https://doi.org/10.1111/j.1439-0418.1989. tb00475.x.

Neuenschwander P, Madojemu E. 1986. Mortality of the cassava mealybugs, Phenacoccus manihoti MAT-FERR. (Hom.: Pseudococcidae), assosiated with an attack by Epidinocarsis lopezi (Hym. Encyrtidae). Bulletin de la Societe Entomologique Suisse 59:57-62.

Neuenschwander P, Schulthess F, Madojemu E. 1986. Experimental evaluation of Epidinocarsis lopezi, a parasitoid introduced into Africa against the cassava mealybug, Phenacoccus manihoti. Entomologia Experimentalis et Applicata 42:133-138. doi: https://doi. org/10.1111/j.1570-7458.1986.tb01013.x.

Neuenschwander P, Sullivan D. 1987. Interactions between the endophagous parasitoid Epidinocarcis lopezi and its host, Phenacoccus manihoti. Insect Science and its Application 8:857-859. doi: https://doi.org/10.1017/ S1742758400023067.

Nwanze KF. 1982. Relationship between cassava root yields and crop infestations by the mealybug, Phenacoccus manihoti. Tropical Pest Management 28:27-32. doi: https://doi. org/10.1080/09670878209370669.

Odebiyi JA, Bokonon-Ganta AH. 1986. Biology of Epidinocarsis [=Apoanagyrus] lopezi (Hymenoptera: Encyrtidae) an exotic parasitoid cassava mealybug, Phenacoccus manihoti 
(Homoptera: Pseudococcidae) in Nigeria. Entomophaga 3:251-260. doi: https://doi. org/10.1007/BF02373334.

Pacheco da Silva VC, Garcia MS, Botton M. 2017. Biology of Blepyrus clavicornis (Compere) (Hymenoptera: Encyrtidae), a parasitoid of Pseudococcus viburni (Signoret) (Hemiptera: Pseudococcidae). Revisita Brasileira de Entomologia 61:257-261. doi: https://doi. org/10.1016/j.rbe.2017.05.003.

Pu'u YMSW. 2019. Relationship between population and intensity of cassava mealybug (Phenacoccus manihoti) attack on Flores Island. Caraka Tani Journal of Sustainable Agriculture 34:6166. doi: https://doi.org/10.20961/carakatani. v34i1.25974.

Sagarra LA, Vincent C, Peters NF, Stewart RK. 2000a. Effect of host density, temperature, and photoperiod on the fitness of Anagyrus kamali, a parasitoid of the hibiscus mealybug Maconellicoccus hirsutus. Entomologia Experimentalis et Applicata 96:141-147. doi: https://doi.org/10.1046/j.1570-7458.2000.00689.x.

Sagarra LA, Vincent C, Stewart RK. 2000b. Fecundity and survival of Anagyrus kamali (Hymenoptera: Encyrtidae) under different feeding and storage temperature conditions. European Journal of Entomology 97:177-181. doi: https://doi. org/10.14411/eje.2000.034.

Tena A, Stouthamer R, Hoddle MS. 2017. Effect of host deprivation on the foraging behavior of the Asian citrus psyllid parasitoid Tamarixia radiata: Observations from the laboratory and the field. Entomologia Experimentalis et Applicata 163: 51-59. doi: https://doi.org/10.1111/eea.12550.

Turling TJC, Wakers FL, Vet LEM, Lewis WJ. Tumlinson JH. 1993. Learning and host-finding cues by hymenopterous parasitoids. Di dalam: Papaj DR, Lewis AC (Eds.), Insect Learning Ecology and Evolutionary Perspectives. hlm. 51-78. New York: Chapman \& Hall. doi: https:// doi.org/10.1007/978-1-4615-2814-2_3.
Umeh EDN. 1988. Development, oviposition, host feeding and sex determination in Epidinocarsis lopezi (De Santis) (Hymenoptera: Encyrtidae). Bulletin of Entomological Research 78:605-611. doi: https://doi.org/10.1017/ S0007485300015455.

van Dijken MJ, van Stratum P, van Alphen JJM. 1993. Superparasitism and sex ratio in the solitary parasitoid Epidinocarcis lopezi. Entomologia Experimentalis et Applicata 68:51-58. doi: https://doi.org/10.1111/j.1570-7458.1993. tb01688.x.

van Lenteren JC, Hemerik L, Lins JC, Bueno VHP. 2016. Functional responses of three neotropical mirids predator to eggs of Tuta absoluta on tomato. Insects 7:34. doi: https://doi.org/10.3390/ insects 7030034 .

Wardani N. 2015. Kutu Putih Singkong, Phenacoccus manihoti Matile-Ferrero (Hemiptera: Pseudococcidae), Hama Invasif Baru di Indonesia. Disertasi. Bogor: Institut Pertanian Bogor.

Winotai A, Goergen G, Tamo M, Neuenschwander P. 2010. Cassava mealybug has reached Asia. Biocontrol News and Information 31:10-11.

Wyckhuys KAG, Rauf A, Ketelaar J. 2014. Parasitoid introduced into Indonesia: Part of a region-wide campaign to tackle emerging cassava pests and diseases. Biocontrol News and Information 35:35-37.

Zang LS, Liu TX. 2009. Food-deprived host-feeding parasitoids kill more pest insects. Biocontrol Science and Technology 19:573-583. doi: https:// doi.org/10.1080/09583150902912673.

Zang LS, Liu TX. 2010. Effects of food deprivation on host feeding and parasitism of whitefly parasitoids. Environmental Entomology 30:912918. doi: https://doi.org/10.1603/EN09266. 